\title{
ASPEK RELIGIUS DAN MORAL NOVEL 99 CAHAYA DI LANGIT EROPA KARYA HANUM SALSABIELA RAIS DALAM PEMBELAJARAN APRESIASI SASTRA DI SEKOLAH MENENGAH ATAS
}

\author{
Randi \\ Institut Agama Islam Negeri Bengkulu \\ Posel : jufrirandy@gmail.com
}

\begin{abstract}
Novel 99 Light In Sky Europe Rimember of the reader A Muslim woman named Hanum Salsabiela. Hanum during her life for three years in Europe made him discover new things about the greatness of Islam in Europe, which describes her faith to God. The aim of the study was to determine the values of the Islamic Religious and moral in order akhidah, sharia, and morals and honesty, compassion, responsibility contained in 99 Novel Light In Sky Europe works Salsabiela Rais Hanum. The method used is a qualitative descriptive method with content analysis techniques to analyze aspects of Religious and Moral contained in 99 Novel Light In Sky Europe Salsabiela Rais Hanum work. Aspects akhidah 17 findings (34\%), aspects of Sharia 16 findings (32\%) and aspects of the findings of Virtue 17 (34\%). As well as aspects of Honesty 18 findings (36\%, Aspects of Love 17 findings (30\%) and 15 findings (30\%) the aspect of responsibility.
\end{abstract}

Keywords: the religious, moral, and literary appreciation

Abstrak : Novel 99 Cahaya Di Langit Eropa mengingatkan pada pembaca Seorang Perempuan Muslim yang bernama Hanum Salsabiela. Bagi Hanum selama dia hidup tiga tahun di Eropa membuat dia menemukan hal-hal baru tentang kebesaran Islam di Eropa yang menggambarkan keimanan dirinya terhadap Allah. Tujuan dari penelitian adalah untuk mengetahui Nilai-nilai Religius islam dan moral dalam tatanan akhidah, syariah, dan akhlak serta Kejujuran, Kasih sayang, tanggung jawab yang terdapat dalam Novel 99 Cahaya di Langit Eropa karya Hanum Salsabiela Rais. Metode penelitian yang digunakan adalah metode deskriptif kualitatif dengan teknik analisis isi yaitu menganalisis Aspek Religius dan Moral yang terdapat dalam Novel 99 Cahaya Di Langit Eropa Karya Hanum Salsabiela Rais. Aspek akhidah 17 temuan ( $34 \%$ ), aspek syariah 16 temuan ( $32 \%$ ) dan aspek akhlak 17 temuan ( $34 \%$ ) serta aspek kejujuran 18 temuan (36\%, aspek kasih sayang 17 temuan (30\%) dan 15 temuan (30\%) aspek tanggung jawab.

Kata Kunci : aspek religius, moral, dan apresiasi sastra 


\section{Pendahuluan}

Kalangan

pemuda-pemudi kebanyakan hidupnya meniru budaya barat. Banyaknya pemuda berusaha memperlihatkan tubuhnya dengan tidak ada rasa malu, mereka tidak memikirkan auratnya yang seharusnya ditutup rapatrapat. Masalah aqidah, syariah, dan akhlak dilupakan bahkan ditinggalkan.

Hadirnya novel 99 Cahaya di Langit Eropa karya Hanum Salsabiela Rais sebagai bahan bacaan yang cukup mendapat perhatian, khususnya bagi mereka yang gemar membaca fiksi, penulis berharap novel ini dapat dijadikan cermin atau bahan pertimbangan dan pemikiran bagi generasi muda dengan memaparkan religius islam, seperti aqidah, syariah, dan akhlak, Maka dengan pembelajaran apresiasi sastra, siswa dapat memahami nilai-nilai kemanusian, dan nilai-nilai ketuhanan sebagai pembentuk kepribadian yang utuh.

Untuk mencapai tujuan dalam pembelajaran apresiasi sastra, guru yang berfungsi sebagai mediator dan fasilitator harus mampu mengupas unsur-unsur yang membangun karya sastra secara utuh dan terpadu. Artinya guru dapat memadukan antara unsur intrinsik dan unsur ekstrinsik dalam pembelajaran apresiasi sastra, sehingga tujuan yang diharapkan dapat tercapai secara optimal.

Novel 99 Cahaya Di Langit Eropa yang dikarang oleh Hanum Salsabiela Rais merupakan salah satu hasil karya sastra fiksi yang dapat dijadikan alternatif materi ajaran dalam pembelajaran apresiasi sastra, khususnya nilai-nilai religius yang terkandung dalam novel tersebut. Selain itu juga mengandung pokok-pokok ajaran agama islam yaitu akidah dan syariah.

Dalam penelitian ini penulis akan mengkaji beberapa teori yang sesuai dengan tujuan penelitian. Hamid (2002:15) mengatakan teori tersebut adalah aspek religi/hakikat nilai-nilai islam dan hakikat novel.
Secara etimologis, kata "agama" berasal dari bahasa Sansekerta, yang berasal dari akar kata gal artinya pergi. Kemudian akar kata gam tersebut mendapat awalan A dan akhiran A, maka terbentuklah kata agama artinya jalan. Maksudnya, jalan untuk mencapai kebahagian. Secara terminologi, agama dan religi ialah suatu tata kepercayaan atas adanya yang agung diluar akal manusia, dan suatu tata penyembahan kepada yang Agung tersebut, serta suatu tata kaidah yang mengatur hubungan manusia dengan yang Agung hubungan manusia dengan manusia dan hubungan manusia dengan alam yang lain, sesuai dengan tata kepercayaan dan tata penyembahan tersebut.

Aspek-aspek religi Islam adalah akidah, syariah, akhlak. Secara Etimologi kata religius berasal dari kata religio atau religo (bahasa latin) yang berarti memeriksa lagi, menimbang, dan merenungkan keberadaan hati nurani. Didalam ajaran agama Islam, pada hakikatnya agama terdiri dari tiga pokok ajaran yaitu : akidah adalah kepercayaan dasar atau keyakinan pokok, syariah adalah hubungan antara agama yang diamalkan menjadi perbuataan dan ucapan yang bertalian dengan Islam, dan akhlak adalah budi pekerti atau kelakukan manusia.

Religius adalah suatu hal yang disampaikan kepada Nabi Muhammad untuk diteruskan kepada umat manusia jika mengandung ketentuan-ketentuan keimanan, perbuatan manusia, dan sistem norma illahi (A.Sadalih,Dkk,1986:53). Definisi akidah menurut para ahli sebagai berikut pengertian akidah secara bahasa (Etimologi). Kata akidah" diambil dari kata dasar "ai-aqdu" yaitu ar-rabth (ikatan), al-ibrah al-im (pengesahan), al-ihkham (penguatan), attawatstsuq (pengikataan dengan kuat), attamaasuk (pengokohan) dan al-its baatu (penetapan). Diantaranya juga mempunyai arti al-yagiin (keyakinan) dan al-jazmu (penetapan). 
Pengertian akidah secara Istilah (Terminologi) Syariah Islam secara garis besar mencakup tiga hal:

Petunjuk dan bimbingan untuk mengenal Allah SWT. Dan alam gaib, yang menjadi pokok bahasan ilmu tauhid. Petunjuk umtuk mengembangkan potensi kebaikan yang ada dalam diri manusia agar menjadi makhluk terhormat yang sesungguhnya (Ahkham syariah, kuluhiyah).

Ketentuan-ketentuan yang mengatur tata cara beribadah kepada Allah SWT. Atas hubungan manusian dengan Allah serta ketentuan yang mengatur hubungan antara manusia dengan sesamaanya dan dengan lingkungannya.

Beberapa ahli berpendapat bahwa sistem Islam terdiri dari Akidah, Syariah, dan Akhlak.

Akidah adalah hukum yang tidak menerima keraguannya bagi orang yang menerimanya (Abdul bin Abdul Hamid Al Ansyar,2000:17)

Syariah adalah amalan-amalan lahiriah-formal yang ditetapkan dalam ajaran agama melalui Al -Qur'an dan Asunah (totok,2005;17). Akhlak adalah suatu sikap yang memiliki sifat-sifat terpuji, keutamaan, berbagai kesempurnaan, dan keagungan yang mulia (Syekh Ali Ahmad Al-Jurnawi,1982 : 1556).

Dalam bahasa inggris kata religius adalah feeling or sentiment atau suatu perasaan agama, kata religius berarti sifat keagamaan. Dalam batasan ini dikemukkan bahwa "religius adalah suatu hal yang berkaitan dengan keagamaan atau suatu yang diyaakini sebagai salah satu kepercayaan" (Qazaaba,1975;37)

Aqidah adalah bentuk jamak dari kata Aqaid, adalah beberapa perkara yang wajib di yakini kebenarannya oleh hati, mendatangkan ketentraman jiwa, menjadi keyakinan yang tidak tercamuri sedikitpun dengan keraguan-keraguan. Aqidah adalah sejumlah kebenaran yang dapat diterima secara mudah oleh manusia berdasarkan akal, wahyu yang didengar, dan fitrah.

\section{Metode Penelitian}

Metode penelitian yang digunakan adalah metode deskriptif kualitatif dengan teknik analisis isi, yaitu menganalisis aspek religius dan moral yang terdapat dalam novel 99 Cahaya Di Langit Eropa karya Hanum Salsabiela Rais.

Subjek penelitian ini adalah seluruh bagian yang berada dalam novel 99 Cahaya Di Langit Eropa karya Hanum Salsabiela Rais. Dalam novel 99 Cahaya Di Langit Eropa terdapat 410 Halaman dan 10 Judul bab. Teknis yang digunakan dalam penelitian ini secara deskriptif dengan menggunakan analisis isi, menganalisisis setiap adegan pada tiap bab yang dijadikan sampel penelitian.

Instrumen penelitian ini adalah penelitian sendiri dibantu dengan tabel analisis. Penggunaan tabel analisis tersebut bertujuan untuk mengumpulkan dan mengolah data-data sehingga dapat mempermudah penelitian dalam menganalisis serta menginterpretasikan nilai-nilai islam yang terdapat dalam novel “ 99 Cahaya Di Langit Eropa karya Hanum Salsabiela Rais.

Fokus penelitian ini meliputi aspek religius Islam dalam tatanan aqidah, syariah, akhlak, tanggung jawab, kejujuran dan kasih sayang yang terdapat dalam novel “ 99 Cahaya Di Langit Eropa " Karya Hanum Salsabiela Rais. Kriteria yang digunakan untuk menganalisis data dalam penelitian ini meliputi aspek religi Islam, yakni pokokpokok ajaran Islam yang terdiri dari aqidah syariah dan akhlak, tanggung jawab, kejujuran, kasih sayang dengan rincian sebagai berikut :

1) Akidah adalah segala informasi baik ucapan, fikiran dan tindakan yang dilakukan oleh tokoh dalam novel yang didasari pada keyakinan, keimanan dan kepercayaan dalam tatanan keimanan, ruang lingkupnya meliputi rukun iman yang ke enam yakni :

1. Percaya kepada Allah

2. Percaya kepada Malaikat 
3. Percaya kepada Kitab

4. Percaya kepada Rosul

5. Percaya kepada hari Kiamat

6. Percaya kepada Qada/Qadar

Temuan Adegan 1

"Bagi saya berada di Eropa selama lebih dari tiga tahun adalah pengalaman yang tidak ternilai harganya. Saya mencoba membuka mata dan hati saya menerima halhal baru yang merefleksikanya untuk memperkuat keimanan saya".

Temuan Adegan 2

"Akhir dari perjalanan selama tiga tahun di Eropa justru menghantarkan saya pada pencarian makna dan tujuan hidup. Makin mendekatkan saya pada sumber kebenaran abadi yang maha sempurna".

Temuan Adegan 3

"Sekarang tekat hanya satu : menjadi perempuan solehah yang menjaga keluarga dan keharmonisan rumah tangga. Itu saja, katanya".

Temuan Adegan 4

Fatma tersenyum sambil mengelus-elus rambut putri semata wayangnya. Dia menarik nafas dalam-dalam lalu meghembuskanya. "Aku tahu dia sedang berpikir bahwa perkataanku ada benarnya". Syariat yakni semua informasi baik fikiran, ucapan dan tindakan tokoh dalam novel yang menyatakan hubungan antara manusia dengan Allah sebagai tindakan ibadah dalam arti khas yang meliputi rukun Islam yaitu :

1. Syahadat

2. Shalat

3. Zakat

4. Puasa

5. Haji

Temuan adegan 5
"Serta hubungan antara sesama manusia dan alam sekitar sebagai bentuk ibadah dalam arti yang luas".

\section{Temuan Adegan 6}

"hmm... aku hanya berdoa mudah-mudahan demikian. Hanya satu yang bisa diamini semua orang, Francois Menou, jendral keercayaan Napoleon, bersyahadat setelah kembali dari Mesir".

Temuan Adegan 7

"Aku tiba-tiba teringat bahwa islam di sebarkan dengan cara indah di indonesia tanpa pemaksaan atau perkumpulan darah".

Temuan Adegan 8

"Orang-orang Singapura Melayu itu ternyata rombongan pengajian muslim orang tua".

Temuan Adegan 9

"Atma mendekapku. Dia tampak begitu bahagia melihat sertifikat bahasa Jerman yang memuat nilai-nilai ujiannya".

Temuan Adegan 10

"Aku memandang Baran yang tiba-tiba merengek lagi di boks tempat tidurnya. Kuraih dan kubopong dia”.

Temuan adegan 11

"Aku berusaha meresapi kata-kata fatma. Menjadi agen islam yang baik di eropa".

Temuan Adegan 12

“ Terima kasih. Ayse agaknya sedikit demam. Aku harus segera membawanya pulang, "kata Ftma menolak ajakanku dengan halus".

\section{Pembahasan}

Dalam bab ini akan diuraikan deskripsi data, pengolahan data, interpretasi data, pembahasan dan keterbahasan penelitian.

Tabel

Prosentase Hasil Penelitian "99 Cahaya Di Langit Eropa” Karya Hanum Salsabiela Rais 
Aspek Religius

\begin{tabular}{|c|l|c|c|}
\hline & $\begin{array}{c}\text { Aspek } \\
\text { Analisis }\end{array}$ & Jumlah & Persentase \\
\hline 1 & Aqidah & 17 & $34 \%$ \\
\hline 2 & Akhlak & 16 & $32 \%$ \\
\hline 3 & Syariah & 17 & $34 \%$ \\
\hline
\end{tabular}

Aspek Moral

\begin{tabular}{|c|l|c|c|}
\hline No & $\begin{array}{l}\text { Aspek } \\
\text { Analisis }\end{array}$ & Jumlah & Persentase \\
\hline 1 & Kejujuran & 18 & $36 \%$ \\
\hline 2 & $\begin{array}{l}\text { Kasih } \\
\text { sayang }\end{array}$ & 17 & $34 \%$ \\
\hline 3 & $\begin{array}{l}\text { Tanggung } \\
\text { jawab }\end{array}$ & 15 & $30 \%$ \\
\hline
\end{tabular}

Berdasarkan tabel III (dapat di ketahui bahwa dalam novel "99 Cahaya Di Langit Eropa terdapat 100 Informasi yang menunjukkan ketaatan sang tokoh terhadap pokok-pokok ajaran akidah berjumlah 17 dengan $34 \%$, akhlak berjumlah 16 dengan $32 \%$ dan syariah berjumlah 17 dengan $34 \%$ serta kejujuran berjumlah 18 dengan 6\%, kasih sayang berjumlah 17 dengan $4 \%$ dan tanggung jawab berjumlah 15 dengan $30 \%$.

Setelah peneliti membaca dengan seksama novel 99 Cahaya Di Langit Eropa karya Hanum Salsabiela Rais sungguh mengagumkan dan membuat peneliti menjadi terkagum dengan isi, bahasa dan nilai sastra Islam yang sangat kental di dalamnya. Sarat sekali dengan aspek pendidikan Islam dalam kehidupan seharihari, tokoh-tokoh utama yang dapat dijadikan teladan bagi pembaca novel tersebut.

Berdasarkan hasil penelitian, maka dapat disimpulkan bahwa: Aspek religius dalam novel 99 Cahaya Di Langit Eropa karya Hanum Salsabiela Rais,terdapat 34 $\%$ temuan yang termasuk akidah, $32 \%$ temuan termasuk aspek akhlak dan $34 \%$ temuan yang termasuk aspek syariah. Aspek moral dalam novel 99 Cahaya Di Langit Eropa karya Hanum Salsabiela Rais, terdapat $36 \%$ temuan yang termasuk kejujuran, $34 \%$ temuan termasuk aspek kasih sayang dan $30 \%$ temuan yang termasuk aspek tanggung jawab. Hal ini di ambil dari 52 judul kecil di random, maka yang di teliti adalah 10 dengan temuan 50 temuan adegan. Hasilnya adalah :

Aspek akidah 17 temuan $=34 \%$

Aspek Akhlak 16 temuan $=32 \%$ Aspek Syariah 17 temuan $=34 \%$ Aspek Kejujuran 18 temuan $\quad=36 \%$ Aspek Kasih sayang 17 temuan $=34 \%$ Aspek Tanggung Jawab 15 temuan $=30 \%$

\section{Simpulan}

Novel 99 Cahaya Di Langit Eropa" karya Hanum Salsabiela Rais ini adalah novel yang mengandung banyak nilai-nilai religius, pada setiap tindakan, ucapan maupun pikiran. Berdasarkan pemaparan di atas karya sastra berupa novel merupakan sarana yang sangat baik untuk membentuk akhlak murid dengan hikmah atau amanat yang terkandung dalam novel. Oleh karena itu, guru sastra perlu mengadaptasikan pembelajaran novel atas sastra demi perbaikan dan meningkatkan pembelajaran sastra di sekolah.

\section{Daftar Pustaka}

Ahmed. Ali Syekh. 2005. Al- Jurnawi. Sinar baru: Bandung.

Gazalba, Sidi.1998. Islam dan Kesenian. Pustaka Al Husna: Jakarta.

Hamid Al-ansyar, Abdul bin Abdu. 2002. Akidah lengkap. Jakarta: Pustaka Ibnu Kastsir.

Sadalih. Dkk. 1986. Pendidikan Agama Islam. Bulan Bintang: Jakarta. 
ISSN 2655-3031 (P)

ISSN 2655-7851 (E)

Tim Penyusun Kamus Pusat dan Totok. 2005. Al-Quran dan Asurah. Pengembangan Bahasa. 1997.

Kamus Umum Bahasa Indonesia.

Gramedia: Bandung.

Gramedia: Jakarta. 